\title{
OPEN
}

\section{4 \\ The Academic Book of the Future and the Need to Break Boundaries}

\author{
Jenny McCall and Amy Bourke-Waite
}

Abstract: Market research demonstrates that scholars' attitudes towards monographs are changing, and that there is appetite for a shorter monograph form. The introduction of mid-length research format Palgrave Pivot in 2012 has proved that such a venture can be successful, and that more flexibility and speed may hold the key to the academic book of the future in humanities and social science research. In this chapter Jenny McCall, Global Head of Humanities at Palgrave Macmillan, and Amy Bourke-Waite, Senior Communications Manager at Palgrave Macmillan, consider the demand for Palgrave Pivot and similar mid-length offerings from academic publishers, the reception they have received from the academic community, and where we might go from here.

Keywords: academic publishers; market research; mid-length offering; Palgrave Pivot; print on demand; publishing speed; shorter monograph form

Lyons, Rebecca E. and Samantha J. Rayner (eds). The Academic Book of the Future. Basingstoke: Palgrave Macmillan, 2016. DOI: 10.1057/9781137595775.0010. 
Traditional methods of publishing academic research, for scholars working in the humanities, business or social sciences, have been to choose to publish either one or more journal articles, or a monograph. Both follow standard formats which were originally dictated by the limits of printing presses. Most scholarly journal articles are between 7,000 and 8,000 words, and most scholarly print books are between 70,000 and 110,000 words in length, with little flexibility for any word count in between. Scholars whose research findings naturally falls in between those word counts have, for hundreds of years, either separated their long research into a number of journal articles (which requires a huge time commitment) or have expanded their word counts unnecessarily to fit the requirements of a monograph.

Reform of the status quo has been possible for a while. As sales of print monographs decline, digital publishing has been slowly on the increase. Journal publishing has embraced digital since the early 1990s, and sales of ebooks are growing, albeit slowly (according to analysts Simba, ${ }^{1}$ they still only represent 6 per cent of sales). Meanwhile, printon-demand technology has enabled publishers to run smaller print runs at increasingly lower cost and higher quality, further freeing content from the restraints of physical printing. In 2010, an article in The Economist claimed that 'About 10\% of Cambridge University Press's sales of academic and professional titles are generated by books printed on demand - compared with $3 \%$ five years ago. Before POD, if sales of one of the publisher's books dropped below 50 copies a year, it was taken out of print. Now a publisher can keep titles available forever.'2

Emboldened by ad hoc conversations between Palgrave Macmillan editors and their authors, who seemed frustrated by having to adhere to what many saw as arbitrary boundaries set by the limits of traditional publishing and printing, in 2011 Palgrave carried out a programme of quantitative and qualitative research to understand how we might improve the academic publishing landscape.

The Palgrave Macmillan Research Panel was established in October 2011, and was formed of 1,268 researchers recruited from a wide range of disciplines and geographic locations across the humanities and social sciences (HSS). The in-house team devised and circulated a survey to comprehensively investigate the panel's views on the process of HSS publishing and specifically on the length of publishing formats. Of the responders, 93 per cent had published one or more peer-reviewed 
research article in the last five years, while 54 per cent had published a peer-reviewed monograph in the last five years. ${ }^{3}$

Two-thirds (64 per cent of the 870 who responded to the survey) felt that the length of journal articles was about right, while for monographs this figure was 50 per cent. The results demonstrated that a number of authors ( 36 per cent journal article authors and 50 per cent monograph authors) were not satisfied with the formats available to them. Almost all those who felt that the length was not right said that the length was too long. The results showed that only 16 per cent believed that current outputs (journal articles and monographs) were sufficient. Of those who felt that a mid-form was a good idea, or who were neutral, 84 per cent indicated that they would be likely to publish in this format. ${ }^{4}$

The survey responses confirmed the suspicion of the Palgrave Macmillan editors that for some members of the academic community, a lack of mid-length publication options and slow production times represented a real problem. A mid-length format for original research which published faster would represent a solution to that problem. However, the editorial standards our authors expected could not be compromised.

At this time, the mid-length research that was available consisted of condensed summaries of existing research. Springer, one of the bigger academic publishers, announced SpringerBriefs in November 2010. SpringerBriefs are concise summaries of cutting-edge research and practical applications across a wide spectrum of fields, usually between 50 and 125 pages in length. Springer produce versions in print, ebook, and MyCopy for readers to access 24 hours a day, and boast a quick turnaround for production.*

Similarly, Princeton Shorts were launched in 2011, an initiative by Princeton University Press. These were brief selections taken from previously published influential Princeton University Press books and produced exclusively in ebook format. ${ }^{5}$

Based on the market research we had undertaken, we believed that there was demand for high-quality, original, peer-reviewed content produced quickly. Consistently, participants expressed extreme dissatisfaction with the length of time it takes to produce a typical monograph. Many wanted to be able to publish research reacting to current affairs more quickly, especially in response to the Research Excellence Framework's request for academics to prove their works' impact. 
The then Managing Director of Palgrave Macmillan Sam Burridge summed it up effectively when she told the London Review of Books blog: 'Original, cutting-edge research is the fire that fuels knowledge and education. Without the dissemination of new thought, new ideas, and challenges to current thinking, textbooks don't change, we don't learn from the past, and society doesn't advance. What we publish today will impact what our children study tomorrow, our social policy, and how businesses are run' ${ }^{6}$

She added: 'Our role as a publisher now goes beyond the selection and dissemination of content. It's about ensuring the impact of research is at least equal to its importance. The humanities and social sciences find it much harder to be heard than the science subjects, as there is less funding and fewer tools available to support our academics. But we see our role as working to change this, breaking down boundaries, and in doing so, helping research to improve our world.'

Palgrave Pivots are a digital-first, peer-reviewed, original research format of around 30,000-50,000 words, with a commitment to publish the books within 12 weeks of acceptance. All elements of the Palgrave Macmillan publishing process were interrogated to allow for the mid-length format and enable faster publication. Authors are asked to answer any questions from copy-editors and typesetters very rapidly, and a wide range of attractive template cover designs are used instead of bespoke designs. In an interview with the Vulpes Libris blog, Ben Doyle, Commissioning Editor for Literature at Palgrave Macmillan, reinforced the integrity of the process. He said: 'All [Palgrave Pivots] are copy-edited and typeset by us and we certainly wouldn't expect authors to present camera-ready copy. Part of the service that we provide as a publisher is the layout/typesetting and editing ... and we wouldn't dream of compromising on this to cut costs or to simply speed things up.'

Print copies are available on demand. In order to ensure that the publication format would be used by academics in practice, Palgrave Macmillan liaised closely with stakeholders including librarians and booksellers to ensure that they would be promptly announced and correctly classified. The Higher Education Funding Council for England (HEFCE) confirmed that research outputs published with Palgrave Pivot are eligible for the UK's 2014 Research Excellence Framework (REF) subject to all other criteria being met. $^{8}$

October 2015 will be the third anniversary of the launch of Palgrave Pivot. In that time, we will have published over 550 books, which have 
taken an average of ten weeks to publish from acceptance. The shortest time to publication was Kath Woodward's Sporting Times, which was published in five weeks. The average page length is 132 pages, and the shortest 78 pages.

Palgrave Pivot titles are published by authors based at institutions all around the world, and they are already making an impact. For example, the Palgrave Pivot Adoption: A Brief Social and Cultural History by Peter Conn was published in January 2013 and cited in an Amicus Brief to the United States Supreme Court in opposition to Proposition 8, which would have restricted the recognition of marriage to same-sex couples. Conn would not have been published in time to influence the legislation if he had not chosen publish through Palgrave Pivot. Palgrave Pivot has been useful in accelerating academics' careers too. Sue Ellen Henry, author of Children's Bodies in Schools, wrote to her editor in August 2015 on the positive impact having written a Palgrave Pivot had on her tenure application. She said: 'I did get promoted (effective August) and while the committee doesn't give precise details about the review, I have to believe that having a book was a major supporting feature of my dossier. Indeed, I believe that one of my external reviewers learned of my book through the review process and then invited me to speak in a grad course via Skype on the topic.'

Ben Doyle described how Palgrave Pivot has changed the way he commissions: 'In terms of the kind of material that we've seen submitted for the format, the variety really has been surprising. I've published slightly more focused studies that require more room than a journal article affords but that couldn't be usefully padded out to monograph length. That said, I've also found the Pivot model to be a good length for particular types of work - work written in a more essayistic style, for instance, or work that adopts a more polemical tone. Many of the academics that I've discussed the format with have viewed it as an excellent length at which to make an initial intervention into an emergent area upon which other academics can then build.'

Attitudes often change slowly in academia, and Palgrave Macmillan was prepared for adoption of the mid-length format to take some time. As Leonard Cassuto notes in his 2013 article for The Chronicle of Higher Education: 'The new, midsized kid on the block has a future, but [...] it's not yet clear how long it will take to gain full welcome on the playground. Academe is conservative (with a small "c"). Such conservatism may guard against fads, but it may also slow change that can be necessary.' 
Cassuto quoted one English professor at a state university who said: 'My sense would be that established scholars will have to give these new kinds of venues credibility first before more vulnerable younger ones can risk counting on them... That's just pragmatism speaking.' A dean interviewed by Cassuto speculated that tenure committees, deans and provosts would be 'more flexible than most might assume' but that 'the real conservatism on these questions comes from faculty who are afraid of looking too different from their peers. ${ }^{10}$

However, Sam Burridge was amazed to see how academics reacted to the launch of Palgrave Pivot. She said: 'Authors have responded incredibly positively. In the 18 years I've been in publishing I've never been involved in a product with such a positive response... I don't normally get authors emailing me directly, praising us as a publisher.' The hundreds of books published since then attests to that. ${ }^{11}$

Recently, Goldsmiths University Press was launched in tandem with an invitation for academics to submit proposals for short or mid-length monographs, as well as short book and pamphlet series. Press director Sarah Kember told The Bookseller that the Press sought 'thought-inaction, provisional or process-capturing work' such as briefs, scripts, blogs, storyboards, notebooks, essays, clips, and previews. ${ }^{12}$ It is also interested in non-standard modes and forms of communication, such as an article in the form of a comic or graphic novel.

Indeed, the market for mid-length research seems to be going from strength to strength. There are also now Stanford Briefs, an imprint from Stanford University Press, running at 20,000 to 40,000 words in length. They publish bite-sized original research in essay format, but aimed at a wider, more popular audience (as are Sage Swifts and Policy Press Shorts). In 2013, Palgrave Pivot introduced an Open Access option for authors who wish for their work to be freely accessible and shareable at point of publication. Much has been made, in the last few decades, of the potential 'death of the monograph, ${ }^{13}$ but despite print sales declining recently, the slow but inexorable rise of digital and the influx of innovations such as mid-format research shows that the monograph still has life.

\section{Notes}

${ }^{*}$ As part of Macmillan Science and Education, in 2015 Palgrave Macmillan merged with Springer. 
1 E. Newman (2014) Simba Information Global Social Science and Humanities Publishing 2013-14, http://www.simbainformation.com/Global-SocialScience-7935107/, accessed 8 October 2015, p. 26.

2 The Economist (25 February 2010) 'Just Press Print', http://www.economist. com/node/15580856, accessed 10 September 2015.

3 H. Newton (March 2013) 'Breaking Boundaries in Academic Publishing: Launching a New Format for Scholarly Research', Insights 26(1): 70-76.

4 Newton, 'Breaking Boundaries in Academic Publishing.

5 Princeton University Press website, http://press.princeton.edu/titles/9803.html, accessed 21 August 2015.

6 S. Burridge (2013) '5 Minutes with Sam Burridge: "Palgrave Pivot is Liberating Scholarship from the Straitjacket of traditional Print-Based Formats and Business Models"', LSE Review of Books, http://blogs.lse.ac.uk/ lsereviewofbooks/2013/10/28/palgrave-pivot-10o-hours/, accessed 1o September 2015.

7 Vulpes Libris (2015) 'Palgrave Pivot: Mopping Up the Mid-Length Manuscripts', Vulpes Libres blog, https://vulpeslibris.wordpress.com/2015/04/29/ palgrave-pivot-mopping-up-the-mid-length-manuscripts/, accessed 20 August 2015.

8 Newton, 'Breaking Boundaries in Academic Publishing.

9 Vulpes Libris, 'Palgrave Pivot'.

10 L. Cassuto (12 August 2013) 'The Rise of the Mini-Monograph', The Chronicle of Higher Education, http://chronicle.com/article/The-Rise-of-the-MiniMonograph/141007/, accessed 20 August 2015.

11 S. Burridge (2013) '5 Minutes with Sam Burridge'.

12 B. Page (30 July 2015) 'Goldsmiths to Launch “Inventive” University Press', The Bookseller, http://www.thebookseller.com/news/goldsmiths-launchinventive-university-press-308334, accessed 20 August 2015.

13 J. Wolf Thomson (2002) 'The Death of the Scholarly Monograph in the Humanities? Citation Patterns in Literary Scholarship', Libri 52: 121-36.

(c) (i) Except where otherwise noted, this work is licensed under a a copy of this license, visit https://creativecommons.org/version4 